\title{
Economic Benefits from Biking Trails and Greenways
}

\author{
Kalyan Chakraborty \\ Northern State University, USA \\ E-mail: kalyan.chakraborty@northern.edu
}

Received: May 2, $2019 \quad$ Accepted: May 17, $2019 \quad$ Published: June 3, 2019
doi:10.5296/ber.v9i2.14727 $\quad$ URL: https://doi.org/10.5296/ber.v9i2.14727

\begin{abstract}
Due to a growing need for health and wellbeing of the urban population and revitalization of the rural economies biking has become one of the top recreational activities is the U.S. While the impact of individual health and wellbeing from biking activities well recognized in the literature, the economic impact of bike tourism in rural communities is less recognized. The purpose of this paper is to review the studies on the economic impact of biking trails and greenways on the local communities and provide a guideline on how to undertake such studies based on available methodologies in the literature. In doing so, the paper discusses the objectives and goals for creating infrastructure for greenway and biking trails in the local communities including methodologies used to assess the economic impacts. This study concludes that for a long-run sustainable development, local community's social and economic resources that already exist can be utilized for building biker friendly communities.
\end{abstract}

Keywords: Biking trails, Greenways, Economic, Impact, Sustainable, Community, Rural, Tourists, Travelers, Social capital

\section{Introduction}

Over last five years mountain biking has become one of the most popular outdoor activities in the U.S. According to a report (Lane, 2017) annually, cycling alone contributes $\$ 133$ billion to the U.S. economy, supports 1.1 million jobs, and generates $\$ 18$ billion tax revenue. It also creates $\$ 50$ billion non-cycling sector businesses such as, meals, hotel lodging, clothing, and entertainment. A study by OIA (2012) found outdoor recreation sector as a whole manufacturing, retail, and service sector jobs related to hiking, biking, hunting, fishing and other sports provide more jobs than any other sector in the U.S economy. The annual growth rate for the recreation sector is 5 percent over last 5 years. Since many of the rural/urban communities surrounding mountain biking destinations also have natural resources these economies have experienced the economic effect of recreational activities these bikers bring to their communities. Bicycling is boosting America's economic health. In Portland, the entire bicycle network in the city built for the cost of one mile of urban freeway. In Baltimore 
for every dollar spent on bicycle projects created twice as many construction jobs per dollar spent on road projects (Flusche, 2012).

The objective of this study is to provide a synthesis of the recent economic impact studies on biking trails and greenways for revitalizing the rural economies and improving health, wellbeing, and recreational benefits for the urban societies. The contribution of this paper lies in its ability to present evidences from the existing studies on the positive impact of biking trails and greenways for economic development in a time when most of the city and county managers face budget crunches. We believe this study will be especially helpful to the researchers, policy makers, and city officials planning for the efficient use of their resources.

\section{Why Bicycling is good for the Economy?}

Several studies have mentioned numerous benefits that may accrue to the communities that promote and maintain greenways and biking trails in the neighbourhood. People who ride bikes buy bikes that creates jobs in bike shops and apparel stores. Bikers also purchase other goods and services as a result, bike accessible businesses benefit by supplying those goods/services to these consumers. People who rides bikes most probably will visit the local stores and business more frequently. People who ride bikes on vacation also buy food, fuel, hotel stay generating millions of dollars to the cities and towns that would not otherwise happen. Flusche (2012) recommends the best way to attract the bikers and create these benefits in the community is by creating an infrastructure that makes it more attractive for the people to ride.

\section{Major Objectives for Creating Biking Trails and Greenways}

The fundamental goal or objective for creating biking trails and greenways in a community are as follows: (1) Trail opportunities contribute to the local economy by providing with the means of active transportation to the visitors and the residents in rural and urban areas. (2) Trails and greenways contribute to the value of the property adjacent to it as property owners recognize the quality of life that came with the property. (3) Trails and high-quality natural and cultural resources attract businesses and corporations who recognize the quality of life benefits from the greenways. (4) Trails can provide recreational opportunities and healthier lifestyles reducing the cost of healthcare. Before I discuss these objectives in detail, it is essential to define the trail-oriented development and bicycle tourism. It is also important to understand what bicycle tourism is and who bicycle tourists are.

According to Keeling (1999), "bicycle tourism can be defined as recreational visits, either overnight, or day visits away from home, which involve leisure cycling as a fundamental and significant part of the visit." Beierle (2011) defines bicycle tourists into four groups: (i) Self-contained travellers who usually carry their gears along on the ride and their primary needs are camping, grocery, and internet access; (ii) Ride-centered travellers generally stay overnight in one location and ride during the day. Hence, amenities like hotels and restaurants are important to them; (iii) Event-centered travellers participate in organized rides/events of various length; and (iv) Urban-cycling travellers generally go to a community and spend most of their time in the community riding bicycle and visiting museum, galleries, and places. 
Next section discusses the objectives in detail using references from the literature.

\subsection{Objective 1}

Trail opportunities contribute to the local economy by providing with the means of active transportation to the visitors and the residents in rural and urban areas. Building owners, businesses, and shop owners have recognized the growing interest of active transportation. However, measuring the economic impact of bike tourism on the local economy is a complex process. By attracting visitors both day users and overnight visitors, trails can create new jobs and businesses. For example, visitors from outside the local area may travel to the area to use a destination trail. In addition to the direct effect on business income and jobs, visitors spending has an indirect multiplier effect on the community. Because the employees and business owners spend their wages and earnings in the community and the local/state governments receive more tax revenues. Economic impacts are higher when the trails are linked to the local shops and commercial establishments, which supply the goods and services to the trail users such as, restaurants, groceries, retail stores, campgrounds, hotels, visitor centers, and apparel stores.

\subsection{Objective 2}

Trails and the greenways contribute to the value of the property adjacent to it as property owners recognize the quality of life that came with the property. Trails like any other community assets such as, good schools, hospitals, high paid jobs or low crime rates create an amenity that generates a higher price for nearby homes and properties. The homeowners value the nearby trail as a place to recreate, socialize, and a convenient place for physical activities and safe for cycling to work and school. Headwaters Economics listed several studies that assessed economic impact of trails and greenways on the property values. For example, in Minneapolis/St. Paul area (MN) for every 400 meters closer to the off-street bicycle facility median home price increased by $\$ 510$. In Indianapolis, one study found that the cultural trail was associated with 11 percent price premium for homes sold within half a mile from the biking trail. In New Castel County (DE), properties located within 50 meters of the bike paths sold at a price 4 percent more than other similar homes. Homes in Mathew Valley (WA), within 25 meters of trails sold for a 10 percent premium price. In San Antonio, (TX) neighbourhood trails brought 2 percent premium on home prices and the Greenbelt was associated with a 5 percent home price premium.

\subsection{Objective 3}

Trails and high-quality natural and cultural resources attract businesses as corporations recognize the quality of life benefits from the greenways. Active Transportation and Real Estate - The Next Frontier (2016) mentioned, "Through supporting bike infrastructure, real estate professionals can play a significant role in creating heathier, more sustainable communities..." The report highlights the most recent evolution of urban development is from "car-centric" to "people-friendly" design. Walkability is the top priority for 50 percent of the U.S. residents when they consider where to live. According to U.S. Census, people who travelled to work by bike increased 60 percent between 2000 and 2014. Companies 
seeking to relocate or establish their headquarters are increasingly paying attention to the importance of trails and greenways in choosing locations. For example, Ruby Tuesday Inc. moved its Restaurant Support Center to a site adjacent to Greenway Trails, Maryville, Tennessee. Studies found levels of diabetes, high blood pressure, and obesity are all lower in cities, which have high share of commuters bicycling and walking to work (Bike Walk Alliance, 2014). National Household Travel Survey (2001, 2009) reports nation-wide 40 percent of total auto trips are shorter than 2 miles and 50 percent of personal shopping and 22 percent of work trips are less than 1 mile. However, only 1 percent of all trips in the U.S. are by bicycle and 10.4 percent are on foot (NHTS, 2009).

\subsection{Objective 4}

Trails can provide recreational opportunities and healthier lifestyles reducing cost of healthcare. National Institute of Environmental Health Sciences (NIEHS, 2015) study found if half of short trips (5 miles or less) are made by bicycle the result will reduce death of 1,295 persons and would lower the health care cost per year by $\$ 3.8$ billion in 11 upper Midwestern metropolitan areas. Trails can bring great benefits to the residents where people live and work by providing opportunities for social connections and safe place for recreation, physical activity, and commuting.

Following are some examples where residents surveyed reported benefits of residing close to greenways and trails (Moudon et al. 2005). In Whatcom County (WA), 95 percent of the long-time residents said trails are the major factor to their decision to stay in the area. In Bloomington (IN), residents adjacent to trails mentioned convenience and access to recreation, physical fitness, social connection, and close to natural environment as benefits of living near the trails. In Jackson (WY), 96 percent of the residents stated that outdoor recreation an important factor for making their decision to move or stay in the area. Nine out of 10 residents use pathways and trails every other day in the summer and every 3 days per week in winter. In Missoula (MO), 73 percent of the residents used hiking trails, 56 percent used paved commuter trails, and 49 percent used natural area and wildlife habitat in the past year. In Old Dominion Trail (VA), 95 percent of the trail users come from counties adjacent to the trail and 93 percent identified health benefits from trail as highly important. In North/Eastern Nebraska, 68 percent of the residents adjacent to the trails said had a positive impact on their community and used the trail for recreation daily. In Morgantown (West Virginia), 60 percent of trail users reported exercised more regularly since they began using the trail and 47 percent users reported they got their recommended physical activity from the trail use. A study by Moudon et al. (2005) found cycling is more popular among male, young adults, transit users, and those who are physically active and in good health. The survey was administered in six states and the half of the respondents (cyclists and non-cyclists) expressed availability of trails and bike lanes in the neighbourhood would increase the use of bicycle.

\section{Methodology for Estimating Economic Benefits}

\subsection{Input-output Models}

Economists generally use three common tools for modelling economic impact studies such as, 
Regional Economic Models Inc. (REMI), Regional Input-output Modelling System (RIMS-II), and Economic Impact Analysis for Planning (IMPLAN). The effect of bicycle related economic activities ripple throughout the region creating revenues for businesses, earnings for households, and jobs directly and indirectly in the community. The total economic impact is the sum of three types of impacts - direct, indirect, and induced. Direct Impact - This refers to the initial direct spending by the trail users on goods and services in the local economy such as manufacturing, wholesalers, and retailers. Indirect Impact Economic activities or purchases by the business owners to support their businesses such as, grocery supplies to the restaurants due to rising demand from the cyclists. Induced Impacts Economic activities generated when the workers in the bicycle related businesses and business owners spend their wages and incomes buying goods and services in the community.

According to Bicycling and Walking Benchmark Report (2014), 22 states, 10 out of 52 populous cities and 5 of the midsized cities have conducted economic impact of bicycling. The results from these economic impact studies are listed below: Arizona (2013), direct impact \$120 million; Colorado (2009), total economic impact \$ 498 million; Florida (2011), Orange County total economic impact $\$ 42.5$ million; Iowa (2011), total economic impact $\$ 400$ million; Missouri (2012, Katy Trail), \$18 million; Minnesota (2009) total economic impact \$261 million; Wisconsin (2010) total economic impact \$924 million. Several factors can contribute toward increased economic activities associated with cyclists. For example, the quality of the trails, the amenities supporting the trail use, and whether or not the trails are linked to towns via spur-trails and/or shuttles. In addition, the event-based visitors often return to the community some tourists become permanent residents or second homeowner in the community they toured.

\subsection{Econometric Models}

The impact studies mentioned above only measure the tangible benefits that accrue to the community from biking activities. The intangible benefits associated with any recreational activity such as, biking and/or hiking also creates an intrinsic value to the recreationist. This intrinsic value is defined as, consumer surplus. It is measured as a difference between the actual cost of a trip and the dollar amount a consumer is willing to pay to enjoy a day of biking and/or hiking trip along a trail. The economists use survey to collect data/information from the recreationists and apply sophisticated econometric models to determine the dollar value of a trip specific to a trail, value of each attributes along the trail, and the total use value of all biking trails and the greenways. For example: Siderelis et al. (2010) used mixed logit model and estimated the economic value of six mountain biking trails in Research Triangle Area, North Carolina. The willingness to pay per user per year was $\$ 336.88$ and the economic benefit per user per routing was $\$ 62.50$. When these dollar figures are interpolated across the total number of active bikers in the state, the total use value from biking is generated. Chakraborty and Keith (2000) used multinomial logit model and estimated the economic value of mountain biking in Moab, Utah. The economic benefit per person per trip was $\$ 585$ and the total use value for mountain biking in Moab was $\$ 1.33$ million. 


\subsection{Hedonic Pricing Models}

Economists use standard statistical models called hedonic pricing models to estimate the price premium on property values proximity to trails or greenways. These models compare the price of homes identical in size, bedrooms, bathrooms, age, etc., except their distance from a trail. When the price differences calculated over hundreds of homes, it enables the researchers to estimate the average price premium for homes near trails. For example, Sander et al. (2010) estimated the urban tree cover's value in Dakota and Ramsey Counties, Minnesota. The study found a 10 percent increase in tree cover within 100-meter, increases average home price $\$ 1,371$ and within 250 meters, increases the sale price by $\$ 836$. Homes within 100-250 meter from tree cover increase sale price by 40-60 percent. Sander and Polasky (2009) found for Ramsey County, Minnesota by reducing the distance between a home and a park by 100 meters the sale price increased by $\$ 136$ and reducing the distance from a trail by 100 meters increased the price by $\$ 119$. Cho et al. (2006) found in Knox County, Tennessee the proximity of a home by 1000 feet closer to a local park increased the premium on sale price by $\$ 172$ and proximity to a greenway by 1000 feet increased the premium on sale price by $\$ 368$. Anderson et al. (2006), found in Minneapolis, Minnesota average home price increased between $\$ 246$ and $\$ 1790$ if the distance between the park and the home decreased by 50 percent depending on the type of park.

\section{Summary and Conclusions}

The study demonstrates the growing need for rural communities to revitalize their economies by building biking trails and greenways. For urban communities biking trails and greenways provide opportunities for improvement of health, wellbeing, and recreational avenues. Borrowing from the concepts proposed by Emery and Flora (2006), this study reiterates how the community assets can be transformed into community capital making it as a bicycle friendly community and attract the bikers. This approach is termed as community capital framework (CCF). In their study, the authors view social capital as a critical community characteristic. Social capital can affect as well as affected by the stock and flow of other capitals. National Rural Funders Collaborative (NRFC) defines seven components of community capital such as, natural, cultural, human, social, political, financial, and built capital. Natural capital refers to those assets that resides in a community already possess such as, weather, geographic isolation, natural resources, amenities, and natural beauty. Cultural capital is the filter through which people live their lives, which may include festivals, storytelling, and tradition. Human capital is the skills and abilities of the people in a community that includes education, training, experience, and leadership. Social capital is the connections among people and organizations that bridges and bonds the people the community. Political capital is community's access to power and its ability to leverage relationships with local power structures for community benefits. Financial capital is the financial resources available to the community to invest in capacity building and to underwrite the development of businesses. Lastly, the built capital is the infrastructure supporting these activities.

Rural communities around the world are implementing tourism-based development strategies. 
A study by Purvis (2018) found that an integrative approach to greenway and trails design increases the attractiveness of the rural communities to residents, business, and bike tourists contributing revitalization of these communities. Well-designed greenways and bike paths that capitalize on the local factors can contribute to economic, social, and environmental wellbeing of the residents. This study would provide valuable guideline to the policy makers and researchers as to why it is important to introduce biking trails and greenways in their communities and how to undertake an economic impact study.

\section{References}

Active Transportation and Real Estate - The next frontier. Urban Land Institute April 2016. [Online] Available:

http://uli.org/wp-content/uploads/ULI-Documents/Active-Transportation-and-Real-Estate-Th e-Next-Frontier.pdf

Anderson, S, T., \& West, S. E. (2006). Open space residential property values and spatial context. Regional Science and Urban Economics, V-36, 773-789.

http://doi.org/10.1016/j.regsciurbeco.2006.03.007

Beierle, H. (2011), Bicycle tourism as rural economic development vehicle. [Online] Available: http://hdl.handle.net/1794/11679

Bicycling and Walking in the U.S. Benchmarking Report, 2014. [Online] Available:

www.bikewalkalliance.org/benchmarking.org

Chakraborty, K., \& John, K (2000). Estimating the recreation demand and economic value of mountain biking in Moab, UT: An application of count data models. Journal of Environmental Planning and Management, V-43(4), 461-469.

https://doi.org/10.1080/713676570

Cho, Seong-Hoon., Bowker, J. M., \& Park, W. M. (2006). Measuring the contribution of water and greenspace amenities to housing value: An application and comparison of spatially weighted hedonic models. Journal of Agricultural and Resource Economics, V-31(3), 485-507.

Emery, M., \& Flora, C. (2006). Spinning up: Mapping community transformation with community capital framework, Journal of Community Development Society, V-37(1), 19-35. https://doi.org/10.1080/15575330609490152

Flusche, D. (2012). Bicycling Means Business: The economic benefits of bicycle infrastructure. [Online] Available: https://bikeleague.org/sites/default/files/Bicycling_and_the_Economy-Econ_Impact_Studies_ web.pdf

Headwaters Economics (2016). Trails Research and Sustainable Benefits Library, Spring. [Online] Available: http://headwaterseconomics.org

Keeling, A. (1999). Sustains: Routes for people. [Online] Available:

http://www.sustrans.org.uk 


\section{Macrothink}

Business and Economic Research

ISSN 2162-4860

2019, Vol. 9, No. 2

Lane, S. (2016). Show me the money: Why complete streets make economic sense. [Online] Available:

https://ideas.stantec.com/blog/show-me-the-money-why-complete-streets-make-economic-se nse

Moudon, A. V., Lee, C., Cheadle, A. D., Collier, C. W., Johnson, D., Schmidt, T. L., \& Weather, R. D. (2005). Cycling and the built environment a U.S. perspective. Transportation Research Part D. V-10, 245-261. https://doi.org/10.1016/j.trd.2005.04.001

National Household Travel Survey (NHTS) $(2001,2009)$. [Online] Available: https://nhts.ornl.gov/download.shtml

National Institute of Environmental Health Sciences (NIEHS) (2015). [Online] Available: https://www.niehs.nih.gov/news/events/pastmtg/2015

Outdoor Industry Association (OIA). The Outdoor Recreation Economy: Technical Report on Methodology and Findings. Aug 2012. [Online] Available: www.outdoorindustry.org

Purvis, A. E. (2018). A greenway system approach to developing a linked amenity in rural Ontario. M. S. Thesis. The University of Guelph, Ontario, Canada. [Online] Available: http://atrium.lib.uoguelph.ca/xmlui/bitstream/handle/10214/12960/Purvis_Amy_201805_ML A.pdf? sequence $=3 \&$ is Allowed $=\mathrm{y}$

Sander, H. A., \& Polasky, S. (2009). The value of views and open space: Estimates from a hedonic pricing model for Ramsey County, MN. Land Use Policy, V-26, 837-845. https://doi.org/10.1016/j.landusepol.2008.10.009

Sander, H., A., Polansky, S., \& Haight, R. G. (2010). The value of urban tree cover: A hedonic property price model in Ramsey and Dakota Counties in MN. Ecological Economics, V-69, 1646-56. https://doi.org/10.1016/j.ecolecon.2010.03.011

Siderelis, C., Naber, M., \& Leung, Yu-Fai (2010). The influence of site design and resource conditions on outdoor recreation demand: A mountain biking case study. Journal of Leisure Research, V-42(4), 573-590. https://doi.org/10.1080/00222216.2010.11950219

\section{Copyright Disclaimer}

Copyright for this article is retained by the author(s), with first publication rights granted to the journal.

This is an open-access article distributed under the terms and conditions of the Creative Commons Attribution license (http://creativecommons.org/licenses/by/3.0/). 